\title{
Contract, Crowd, Corpus and Plasma: Architectural and social assemblages
}

\section{Carl Douglas}

This paper springs from Joseph Rykwert's observation, in On Adam's House in Paradise (1981), of a conceptual correlation between Marc-Antoine Laugier and Jean-Jacques Rousseau. It discerns, in the condition of joints in Laugier's Essay on Architecture (1753) and social bonds in Rousseau's Social Contract (1762), an underlying structural logic: what I will call an implicit theory of assemblage. From this initial reference point in the mid-eighteenth century, the paper moves to consider theories of crowds in the late nineteenth century as implicit theories of assemblage, and ultimately advocates the work of Gabriel Tarde as a basis for explicitation of these underlying theories. ${ }^{1}$

\section{Contractual obligations}

"Man was born free, and he is everywhere in chains." The Social Contract begins with chains, and remains entangled in questions of binding (Rousseau 1968: 49). The chain is a figure of arbitrary constraint, and is represented as something to be thrown off. But in Rousseau's text it is not a matter of aspiring to a state of absolute unconstraint. The very concept of society, of a social order, implies some kind or degree of attachment, and it is the proper form of this attachment that is the concern of The Social Contract.

Rousseau makes a primary distinction between the arbitrary bond of the chain and the natural bond of the family, "the oldest of all societies, and the only natural one" (1968: 50). The child is bound to the father by necessity (the maternal bond is never raised), and once the child becomes independent, this bond dissolves: the child and father are freed from this relation and, if it persists, it is by mutual consent: "If they continue to remain united, it is no longer nature, but their own choice, which unites them; and the family as such is kept in being only by agreement" (50). In this shift from dependence to agreement, Rousseau locates the shift from the natural to the social. All legitimate authority, asserts Rousseau, must be based on agreement, and he sets himself the task of describing a society of this kind. Rousseau, who has occasionally been misunderstood as advocating a return to nature, actually describes the social as a second nature. ${ }^{2}$ Natural order does not authorise social order. Social order must consist of covenants, freely entered into.

As Mark Wigley points out, Rousseau explicitly describes the constitution of social order as a building project, for which the ground must be cleared and tested, the structure carefully maintained, and collapse avoided, "as an architect who puts up a large building first surveys the ground to see if it can bear the weight" (Rousseau 1968: 88; see Wigley 1993: 133). The state is a collective identity formed by very specific relationships between individual elements. By freely entering
I. Although French sources are predominant in this paper, I believe the applicability of this study is not exclusively limited to France. However, the development of theories of social cohesion was particularly strong in France due to the experience of the revolutions. See Moscovici (1985) and van Ginneken (1992). 'Explicitation' is Sloterdijk's term (2005).

2. See Lovejoy (1923), who points out that the term 'nature' in Rousseau's writing has a number of meanings that must be distinguished. In The Social Contract, as in the Discourse on Inequality, Rousseau does not look back to an idyllic past, but seeks to disclose the moment at which nature and culture become discrete. 


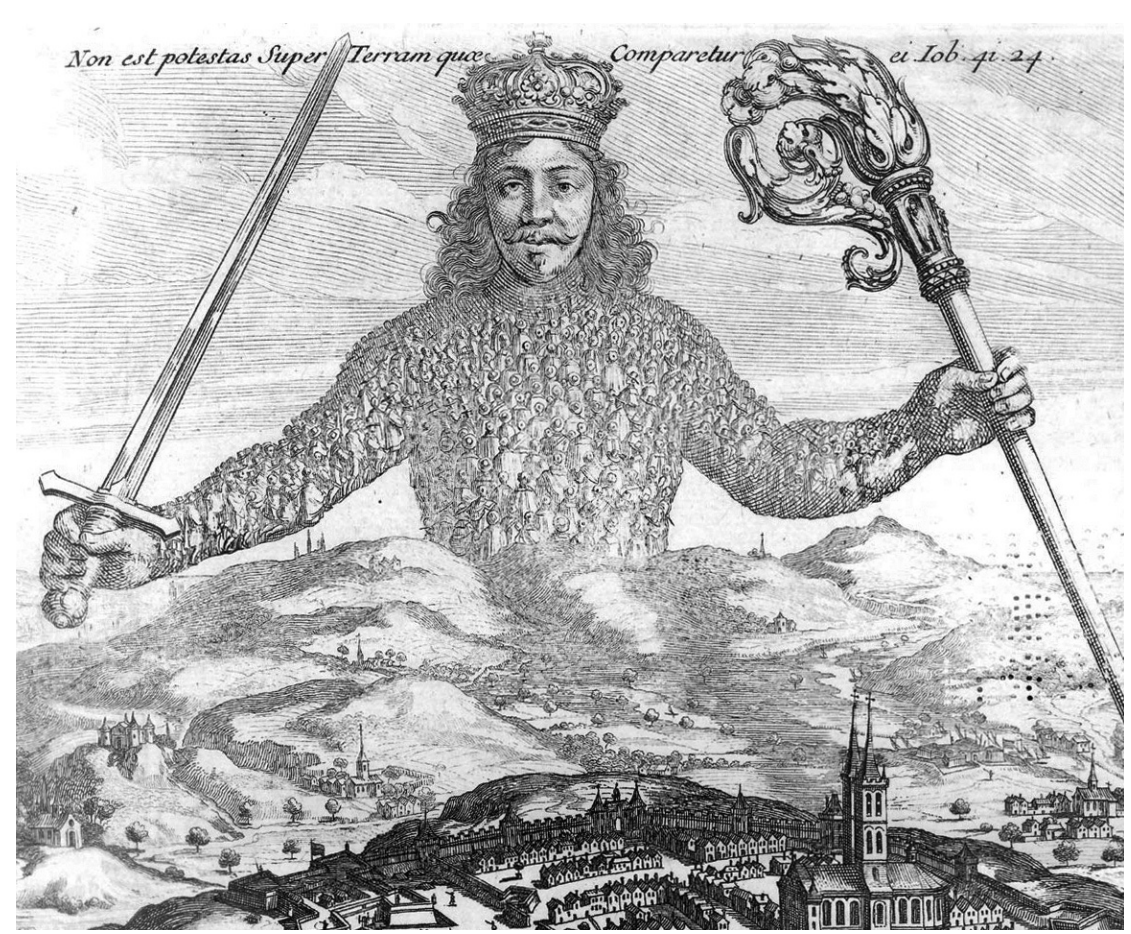

Fig. 1: Frontispiece to Leviathan, Thomas Hobbes, 1651

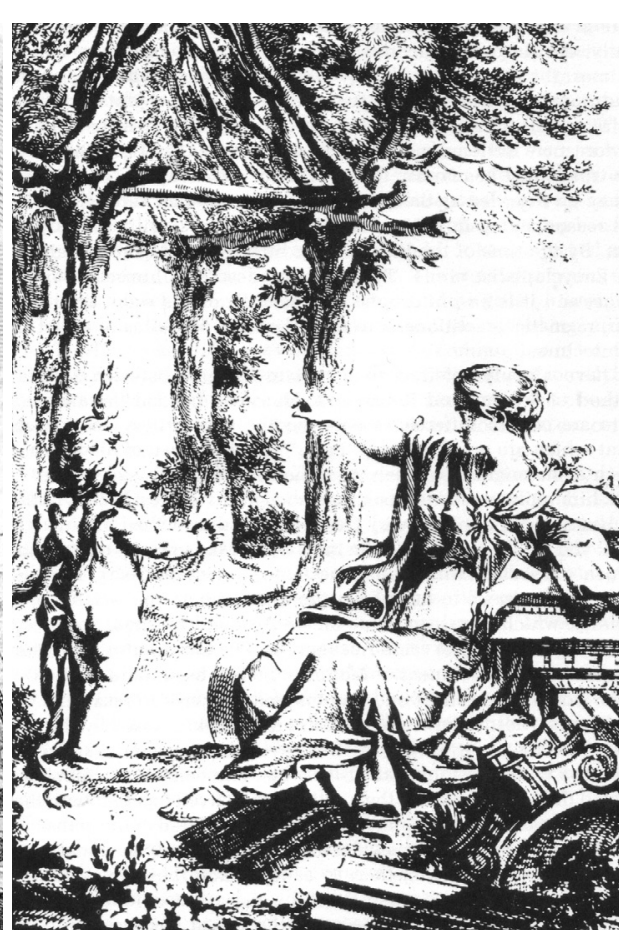

Fig. 2: Frontispiece to 2nd ed. of Essay on Architecture, Marc-Antoine Laugier, 1755
3. There is a useful criticism of the "organismal metaphor" in De Landa (2006: 8-12).

4. For a fuller discussion of the spatiality of power-relations in Hobbes's Leviathan, see McEwen (2007). into the social contract, an aggregate is formed, a corporate body, a "public person ... once called the city" (61). This agglomeration is given its internal cohesion by the social contract to which each individual subscribes. The contract is the fundamental joint, the bond or bind by which the entire social edifice takes shape and holds together. The social body acquires unity, life and will.

Although a social whole is formed, however, the parts must remain autonomous, such that each individual has a private will distinct from the general will: "His private interest may speak with a very different voice from that of the public interest" (63). This freedom runs to the extent that the individual may at any time withdraw from the contract entirely. Society exists only so long as the social contract is freely maintained by its constituents. The freedom to renounce society is essential. The joints of Rousseau's social structure must not be bound or fused. There cannot be forceful constraints in the social contract.

Rousseau's social contract is in many respects a gloss on Hobbes' Leviathan (1651). Hobbes proposed that the state should be conceived as a collective body, of which the sovereign was the head. The famous frontispiece of Hobbes' treatise (Fig. 1) shows what he had in mind: a body comprised of individual humans as cells, all looking up towards the sovereign. Apart from his insistence on the right to withdraw from the collective, Rousseau's innovation is in shifting focus from the exterior relations to interior relations. Where Hobbes begins with the image of a human organism, and proceeds to show how society can be fitted into this authorising metaphor, Rousseau begins with individual connections, and attem pts to discover what the whole body might look like. ${ }^{3}$ Put simply, where Hobbes tendentiously assumed the primacy of social form, Rousseau was concerned with social formation. ${ }^{4}$

Joseph Rykwert has suggested a correlation between Rousseau's primitivism and that of his contemporary, Marc-Antoine Laugier. The famous frontispiece image of Laugier's Essay on Architecture (Fig. 2) is one of the key coordinates for 


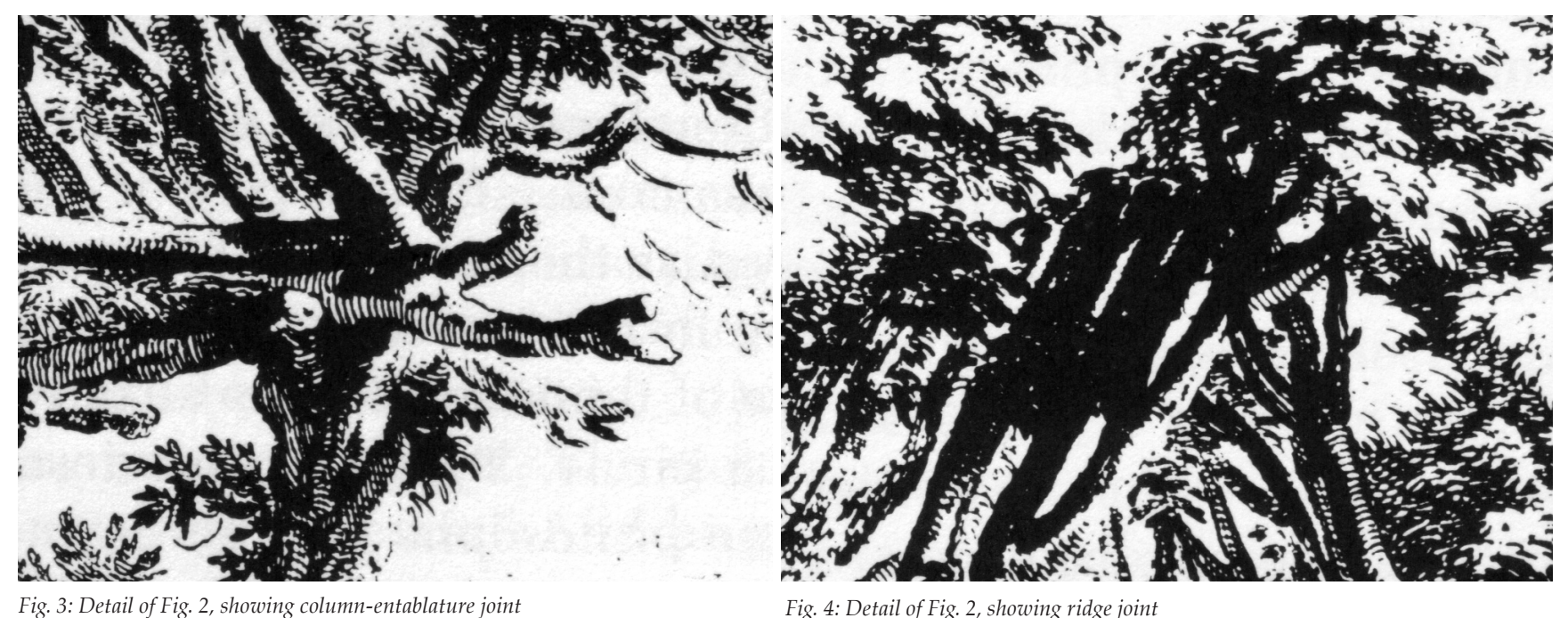

Rykwert's study of the idea of the primitive hut in architectural theory, On Adam's House in Paradise. Laugier proposes that the basic elements of the classical tradition in architecture are already present in an imagined primitive scene: seeking environmental control over light, heat, dampness and air, a primitive man finds four trees arranged in a square, and constructs a raised roof, thus inventing column, entablature, and gable. Rykwert writes, "Allowing for the inevitable differences between the two men, and the differing scale of their enterprises, this view of the authority of the primitive hut is not unlike that which Rousseau attributed to the family as the archetype of social organisation" (1981: 44). In his The Contribution of Art and Science to the Refinement of Manners, Rousseau describes in parallel the socialisation of human beings, and the degenerate elaboration of architecture:

Here is a calm riverbank, dressed by the hand of unaided nature, towards which the eye turns constantly, and which you leave with regret ... then came the height of degradation, and vice was never carried so far as when it was seen, to speak figuratively, supported by marble columns and engraved on Corinthian capitals. (Rykwert 1981: 46-47)

How to house human beings properly is a question allied to that of proper social relations. In his drawing for the second edition of the Essay on Architecture, Laugier's hut is conspicuous for its structural self-sufficiency. The individual elements - the still-living columns, the cross beams and the rafters - all rest together naturally, without pins or bonds (Fig. 3). The four tree-columns have been pruned, and the stumps of the branches become brackets to support the beams. The trees retain their leafy growth, except possibly for the front left tree, which looks as if it has been trimmed back to the trunk. The rafter branches sit up at an improbably steep angle. They rest on the beams without any evident support: under close inspection, the expected bindings are found to be absent, and the rafters do not appear to be notched onto the beams. At the ridge, the rafters rest against one another (Fig. 4). A ridge-beam is possibly hinted at, but looks as if it is suspended under the rafters rather than providing any substantive support. Again, there is no hint that the rafters are bound or pinned together at the top; and they cannot be interwoven, because the branches are conspicuously thick and blunt. Perhaps the gesture of Architecture personified in the foreground could be re-interpreted as a gesture of blame for the collapse of the 
5. Rykwert writes that Rousseau's natural origin exists "in the notational rather than in the paleontological sense" (198I: 47-8), and this is true of Laugier's also.

6. See Frampton (1995)
Ionic edifice in the foreground that has attempted to follow the structural logic of Laugier's hut - in which case it is no wonder that the cherub appears shocked.

It is evident, of course, that Laugier did not intend his hut to be understood as an exemplar of construction practice, but as a moral "first model" (Laugier 1756: 11). It is used to demonstrate the essential elements of architecture, and to exclude those elements that are superfluous additions, "essential defects" (12). It performs the same role (and has the same anthropological non-specificity ${ }^{5}$ ) as Rousseau's primitive family. But to point out the strange condition of the joints in Laugier's image is not entirely perverse - his model does, after all, deliberately express principles of construction. And, in fact, the disjointedness of Laugier's hut is entirely consistent with his thinking about architectural attachment, and the relationship between part and whole. In the Essay on Architecture, there is little written directly concerning joints. Jointing may be amongst those details with which Laugier felt disinclined "to load this little work" for fear they might "trouble and distaste the reader" (xvi). Connection and attachment are, however, important sub-themes of Laugier's text.

In the chapter of his essay that directly addresses construction, the strength of a building is said to depend on the choice of good material, disposed with consideration of load-paths and bearing. Laugier writes, "There are three things which render a wall strong and immoveable. The foundation upon which it bears its thickness, the connection and right line of its parts" (138). It is obvious that in his text he has in mind one type of joint, stacked masonry: this is in spite of what he has asserted about the timber origins of architecture. Stones are to be laid accurately and tightly, "that there may be no void in the thickness of the wall" (141), and the use of mortar, a concession, is to be minimised. Laugier's ideal structure would be held together by nothing other than gravity. Beams are "laid" on the columns. Columns are to "bear immediately upon the pavement, as the pillars of the rustic cabin bear immediately on the ground" (15).

For Laugier, working from the model of his primitive hut, the column was the only proper means of bearing vertical loads. Walls were to be treated as infill panels, concerned solely with sealing up a spatial envelope. Engaged columns are only permitted as a "licence authorised by necessity" (16), but must not be lost into the mass of the wall - they should be engaged "a fourth part at most ... so that even in their use they may always retain something of that air of freedom and disengagement" (16). For Laugier, parts must remain distinct, even while they form an integrated architectural body. They must be seen to be distinct (as the columns must be seen to be distinct from the wall), and they should need a minimum of concern for attachment: there is an expected natural co-dependence of parts. The disconnection of parts, which Laugier encourages, could be seen as a foundational principle for later tectonic conceptions of the joint, the role and expression of which became one of the central preoccupations of modernist architecture. ${ }^{6}$

Laugier and Rousseau share more than an authorising appeal to a fictional primitive scene. Both idealise connections in the same way, envisaging a kind of joint that is held together without binding. Their respective edifices, social and architectural, are complete wholes comprised of individual elements, which must remain free and discrete, even as they constitute this wholeness. Both edifices are only conceivable on the basis of a very particular mereology. The joint is primitive, in the sense that it is taken to emerge from primitive social and 
technical conditions. Although these conditions place the joint close to nature, the joint itself is not understood as natural, except insofar as rationalism is natural. For Rousseau, there are three joints: the paternal bond, the agreement and the chain. The first is natural and primitive, the second rational and natural, the third unnatural and irrational. The social contract is of the second of these orders. Laugier fumbles the question of origin by treating it over-literally, but he too seeks to authorise architectural production by demonstrating it to be a rational and natural assembly.

\section{Crowds as a source of anxiety}

Rykwert's observed correlation indicates the presence of an underlying philosophy or logic of part-whole relationships: an implicit theory of assemblage. This theory structures Rousseau's politics and Laugier's theory of architecture. It was problematised, if not superseded, by the emergence of the crowd. By the end of the nineteenth century, Europe looked back to Rousseau through a hundred years of episodic revolutions, particularly in France. By jumping to the end of this traumatic period, it will become clear just how drastically this underlying philosophy had shifted. ${ }^{7}$

In the nineteenth century the behaviour of collectives, in particular the crowd, became a crucial concern. Associated through revolutionary actions with violence and unrest, it was a source of bourgeois anxiety. During this period, discourses of sociology, criminology, politics, economics, psychology and urbanism are all heavily marked, and in some cases redefined, by a new concern for crowds. In 1895 Gustav Le Bon introduced his book The Crowd: A Study of the Popular Mind by noting the urgency of a satisfactory account of collective behaviour. He did this with an accusatory barb aimed at Rousseau and his philosophical descendants:

Today the claims of the masses are becoming more and more sharply defined, and amount to nothing less than a determination to destroy utterly society as it now exists, with a view to making it hark back to that primitive communism which was the normal condition of all human groups before the dawn of civilisation. (Le Bon 2001: 9) ${ }^{8}$

Where Rousseau's collectives are essentially the product of rational minds, Le Bon's are essentially irrational. The crowd, Le Bon argues, is a psychological entity:

Under certain given circumstances, and only under those circumstances, an agglomeration of men presents new characteristics very different from those of the individuals composing it. The sentiments and ideas of all the persons in the gathering take one and the same direction, and their conscious personality vanishes. A collective mind is formed, doubtless transitory, but presenting very clearly defined characteristics ... It forms a single being, and is subjected to the law of the mental unity of crowds. (2001: 13)

Like Rousseau, Le Bon is concerned with the formation of a greater unity from individual elements, and in both cases there is an appeal to a primitive state of humanity. But while for Rousseau this is a matter of agreement and elevates humans, for Le Bon it is a matter of instinct and degrades them. In becoming part of the crowd, an individual regresses atavistically to a barbaric state.
7. The revolutionary century began with the French Revolution of 1789, and included the July Days of 1830, the February and July Revolutions of 1848 , and the Paris Commune of 187I, as well as many smaller uprisings. Moscovici writes, "If crowd psychology was born in France rather than in Italy or Germany, it was because of the effect of the simultaneous existence of waves of revolutions and the appearance of schools of hypnosis, the aftermath, so to speak, of the Paris Commune and the Nancy hospitals or the Saltpêtrière“ (1985: 82).

8. Le Bon, of course, misunderstands Rousseau. See note 2 above. 
By the mere fact that he forms part of an organised crowd, a man descends several rungs in the ladder of civilisation. Isolated, he may be a cultivated individual; in a crowd, he is a barbarian - that is a creature acting by instinct. He possesses the spontaneity, the violence, the ferocity, and also the enthusiasm and heroism of primitive beings, whom he further tends to resemble by the facility with which he allows himself to be impressed by words and images - which would be entirely without action on each of the isolated individuals composing the crowd. (2001: 19)

The subjection of the individual psyche to the crowd is understood by Le Bon as an actual physical effect on the body. The individual does not retain autonomy, as it does in Rousseau's society. The body enters a special state close to that of hypnosis, in which the higher functions of the brain are suppressed. A collective persona is formed, but this is no society, merely a crowd. A crowd is therefore a state of collapse of the individual, willing, subject. A crowd attains its mental unity at the expense of individual civility. In Le Bon's view, essentially rational civilised individuals degenerate through the formation of crowds, becoming savage, mentally weak, and violent. Rousseau's view is less stark. On their own, humans are savage but, for Rousseau, this also means they are free. The formation of social structures allows the arrival of civility, even as it entails certain vices. There is a loss of savage individualist innocence. There is thus a fundamental disagreement between Le Bon and Rousseau about the state of savagery: for Rousseau the savage is innocent and free, but for Le Bon he is animalistic and irrational. More importantly, from the point of view of the structure of the collective, Rousseau's society is jointed without constraint, while Le Bon's crowds have entered a state of subjection.

The idea that the crowd is something to be mistrusted and feared was shared by many in the later nineteenth century. Baron Haussmann's restructuring of Paris was motivated by a concern for social order and anxiety about crowds. His urban surgery aimed to clarify, de-densify, and provide a spatial hierarchy to chaotic Paris, suggesting a direct correlation between the social patterns that lead to revolution and the spatial organisation of the city: "We have to attack the old neighbourhoods head on ... we have to force the population away from the centre [à une excentricité favorable] ... we have to have the audacity to remake 'quartiers' from top to bottom» (Jordan 1995: 110). In the 1860s, a memo from Haussmann's office worried that Paris had become filled with:

a floating mass of workers who have come to the city [today], ready to leave tomorrow, of families whose members are dispersed throughout the city by their diverse places of work, of nomad renters who are incessantly moving from quarter to quarter, without knowing a fixed residence or a patrimonial place. It is an accumulation of men who are strangers to each other, who are attracted only by impressions and the most deplorable suggestions, who have no mind of their own, since they are not dominated by a strong national feeling (217).

There is no governing structure to this population. They do not have any particular allegiance to place, have fluid connections to each other, and the institutions of the city, and act animally, according to mere stimulations of their senses. Of course, the anxiety in Haussmann's office is directly related to the experiences of the barricades. These provisional structures, thrown up across the narrow 

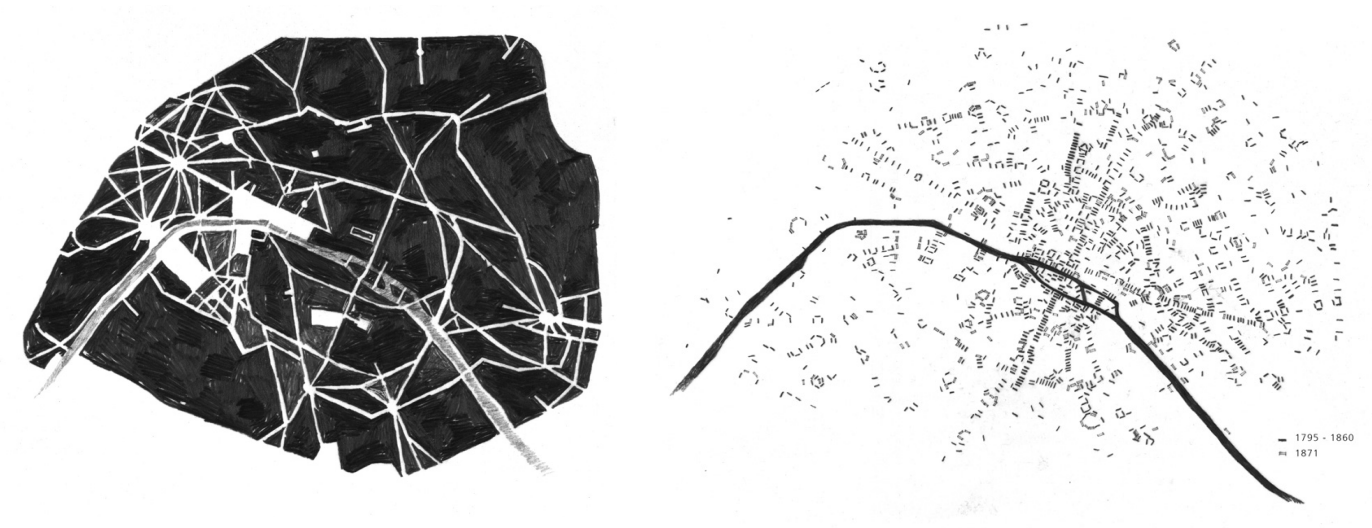

streets of Paris, had been a dominant feature of the revolutionary uprisings of 1830 and 1848. Comprised of detritus and repurposed urban materials (pavers, gates, street furniture, rubble), they had reconfigured the power-relations encoded into the city (Fig. 5). Part of Haussmann's intent in modernising Paris with wide, clean boulevards, was to discipline this unruly material, and hinder the agglomerative architecture of the barricades from forming. Barricades are not constructed so much as they accumulate, and it is precisely in this sense that they reflect the properties of the crowd mistrusted by Le Bon and Haussmann: fluidity, lack of ties, and expedient relationship to place. ${ }^{9}$

There is a symptomatic difference in conceptions of collective action between Rousseau and Haussmann. For the eighteenth-century philosopher, the collective is a desired construction, and the task at hand is the definition and institution of proper social relations. For the nineteenth-century urbanist, the collective provokes unease, and the task at hand is the prophylactic, or at least palliative, disciplining of the materials and population of the city. At the more abstract level of the implicit theory of assemblage, there are also shifts. Crowds and barricades share the property of accumulation, of fluid and ad hoc relations, of detachment and provisionality. This is what, fundamentally, makes them threatening to the intended order of the Second Empire. Haussmann wants to be able to treat the city as a single, cohesive organism that can be restored to health. Haussmann aims to give the city the order of a body, and suppress the order of crowds. ${ }^{10}$

What has not changed is that the management of social assemblages (the crowd) is entangled with the management of built assemblages (the barricades and the city). For Haussmann, politics and the design of urban space are not separate enterprises. Socio-political and spatial orders are essentially connected. Also invariant is the idea that these assemblages can be understood with reference to the primitive. Change happened in how these assemblages are seen to form and the anxiety they now engender. Social structure is no longer seen to be hierarchical and benign, but turbulent, disruptive, even essentially violent.

\section{The body of an organic society}

Peter Sloterdijk writes that in "the disassembly of social conglomerates into individualised complex entities, and their recombination into cooperative ensembles, it becomes clear that the formula of the 'entry of the masses into history' also articulates an architectural problematic" (2007: 64). This problematic is disclosed by the spatial difficulties experienced by revolutionary crowds: "As early as the French Revolution, it became evident that its protagonists would have to
Fig. 5. Schematic plan of Paris in 1871, following Haussmann's public works; and cumulative plan of barricades in Paris, 1795-1871 (after Philippe, 1989).

9. On the architecture of the barricades, and their reconfiguration of the city, see Douglas (2007).

10. For this interpretation of Haussmann's work, see Benjamin (1999) and Jordan (1995) 


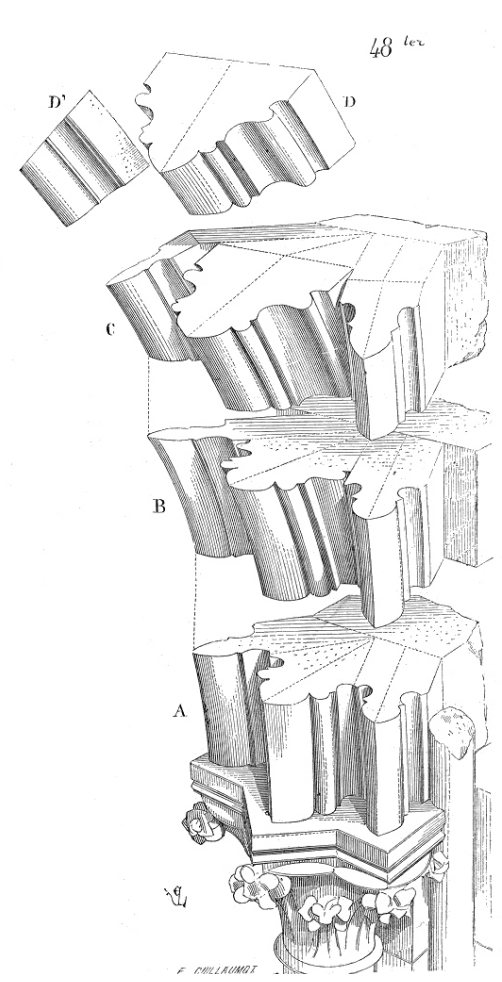

Fig. 6. Drawing of the springing-point of a Gothic arch, Dictionary of French Architecture, Eugène-Emmanuel Viollet-le-Duc (1854). rely on the buildings of the ancien régime and public urban spaces, particularly the squares in front of large buildings, for their gatherings" (2007: 65). Existing palaces and meeting halls simply could not accommodate either the number of participants or the types of event involved, and it was necessary at first to commandeer tennis courts, churches, and public squares. What would be the architecture of the new social order? This question was not easily resolved and remained difficult as the political pendulum swung back and forth. The case of Viollet-le-Duc is noteworthy.

Eugène-Emmanuel Viollet-le-Duc was among the barricade-builders in 1830, and lent his support to the Paris Commune in 1871, although he had worked extensively for the Second Empire government alongside Haussmann. Perhaps due to these sympathies he does not seem to have shared Haussmann's fear of crowds. In fact, he was fascinated by crowd spaces. In his second Discourse, he demonstrates the potential of new materials by proposing spaces for crowds: a concert hall, a market.

Calling for a mixed system of construction, in which cast and wrought iron, brick and stone masonry, and even enameled tile infill would all be developed to maximize their individual capacities in relation to one another, Viollet-le-Duc called his invention an 'organism' which took its place as the next link in a long chain of architectures for mass gatherings. (Bergdoll 2000: 232)

Viollet-le-Duc showed a progressive concern for establishing a proper architecture of the masses. Architecture, in his view, was deeply implicated in the development of a new, organic society. For Viollet-le-Duc, architecture is governed by a principle of growth, working from the level of the individual joint. Kenneth Frampton points out that Viollet-le-Duc, in his Lectures on Architecture (1858-1872), does not once use the term space "in a modern sense" (Frampton 1995: 1). Violletle-Duc's theory of architecture is almost entirely concerned with the practice of jointing and assemblage. Viollet-le-Duc's reading of Gothic order is a response to the logic of autonomy that had, at least since Laugier, dominated classicism. In it, Viollet-le-Duc sought an organic structural model for an organic society. The fascination with an organic logic is played out in Viollet-le-Duc's painstaking analysis of the Gothic system. A detail of the springing-point of a Gothic arch, taken from his Dictionary of French Architecture (1854-1868), illustrates this (Fig. 6). The detail is a fragment, an excised portion of a larger structure, which is in turn severed into parts. Each severed segment is revealed to be distinctly shaped as part of a fluid whole. The arch is not itself present in any one element, but in a line which passes through multiple elements. Unlike Laugier's discrete components, each part of Viollet-le-Duc's ideal architecture has a niche, and no element is autonomous. While Laugier works from an overall diagram, Violletle-Duc works from local relations between individual elements. For Laugier, architecture is a fulfilment of the diagram, and the only rule governing the joints of this structure is the principle of discernible detachment.

The influence of Viollet-le-Duc's organic and tectonic conception of architecture on the development of modernism is well known. But the metaphor of the architectural organism, of organic development, was not ultimately progressive. Although Viollet-le-Duc responded to Laugier, and refocused his interest on the question of connection rather than hierarchy, the sense of a coherent architectural order remains. While he addressed new social organisations, Viollet-le-Duc's 
implicit theory of assemblages persists as a descendant of the Laugian ideal: a singular architectural body. Although the organism metaphor is shared between Viollet-le-Duc and Haussmann, Viollet-le-Duc begins to shift this metaphor towards the interrelations of parts rather than subdivision of wholes. Viollet-leDuc attempts to show of Gothic cathedrals, for instance, that the whole is in many ways the organic development of a system of parts and details. In this respect he betrays, I suggest, the influence of a changing implicit theory of assemblages.

\section{Plasmatic assemblages}

So far, I have tried to demonstrate the existence of implicit theories of assemblage that are manifested in both architectural structures and social structures. Rousseau and Laugier share a theory premised on the irreducible discreteness of parts. Interest and concern about the behaviour of crowds lead to studies such as Le Bon's, in which a new theory is implicit; one which not only posits a new kind of flat, chaotic assemblage, but codes such assemblages as primitive and hostile. Revolutionary barricades threaten the built order of the city in the same way that crowds threaten social and political order. Haussmann arrays the fabric of the city against barricades, attempting to ensure its conceptual, political, and practical manageability. He contends not only against particular crowds but also against the very concept of crowds and he does this by appealing to the ancient image of the city as a body. Viollet-le-Duc's organicism is subtly different from Haussmann's, even accounting for the differences in scale and emphasis of their respective projects. Where Haussmann works down from an idealised image of the whole, Viollet-le-Duc works up from the interrelation of parts.

In what remains of this paper I want to point out a radical, prescient and underexploited analysis of assemblages that arose from the end of the nineteenth century, that of sociologist Gabriel Tarde. Although Tarde's work was not influential at the time of its writing, his analysis has been recovered and refurbished by several important recent theorists of assemblages and provides a bridge to the present for the ideas I have been considering so far. ${ }^{11}$

According to Tarde, the multiplicitous order of the crowd is not an exception: rather, it is the rule, and not only the rule for accumulations of people, but for all accumulations. Tarde insisted that it is proper to talk of cellular, atomic, and stellar societies. A body is a society of organs. A mind is a society of thoughts that cannot properly be said to belong to it. Bruno Latour explains that for Tarde, "to be a society of monads is a totally general phenomenon, it is the stuff of which the world is made" (2001: 121). Tarde generalises the structure of the crowd as a model for all assemblages, human or nonhuman. ${ }^{12}$

Tarde came into direct conflict with sociologist Émile Durkheim by being fundamentally opposed to the idea that the study of societies was the study of unities at a scale greater than that of the individual. His Social Laws (1898) criticises the fallacy "that in order to see the regular, orderly, logical pattern of social facts, you have to extract yourself from their details, basically irregular, and to go upward until you embrace vast landscapes panoramically" (Latour 2001: 124). Durkeim's sociological explanations, Tarde felt, explained the detail with respect to the large-scale, when it was in fact precisely the large-scale which was in question:
1I. Tarde is in fact the source of Le Bon's idea of the group mind, although Le Bon misinterprets this by describing it as a collective ego. It is perhaps because Le Bon's anxious simplification of Tarde's theories appealed to popular conservatism more than the Tarde's own counterintuitive and (apparently) abstract theory that Le Bon was celebrated and Tarde almost ignored.

12. Tarde's concept of societies is taken up by Gilles Deleuze (see, for example, Deleuze, 2004: 157-58) and, subsequently, De Landa (2006). 
Instead of explaining everything by the so called imposition of a law of evolution which would constrain larger phenomena to reproduce, to repeat themselves in some certain identical order, instead of explain the small by the large, the detail by the big, I explain the overall similarities by the accumulation of elementary actions, the large by the small, the big by the detail (Tarde 2002a: 21-22, translation by Latour).

Tarde refused the premise shared by both Rousseau and Le Bon that there could ever be a point when we could move cleanly from talking of interactions and ties at the microscopic scale to analysing the macroscopic operations of a collective. Society was, to borrow Latour's terms, a "confusing plasma ... a brew" instead of an edifice (Latour 2001: 125). For Tarde, a society is not a greater whole, but a radical partiality. Individual elements:

soldiers of those various regiments, provisional incarnations of their laws, pertain to them by one side only, but through the other sides, they escape from the world they constitute ... [they have] other leanings, other instincts coming from previous enrolments ... [they are] made only of sides and facades of beings (124).

The individual is faceted, multiplicitous, split by 'previous enrolments', traversed by tendencies outside itself. At this point it is worth recalling Laugier's hut, the elements of which report such prior engagements. The branches, although repurposed as linear elements, retain the forks, bends and inconsistencies of the tree, and the living columns themselves exhibit stumps where their unruly growth has been disciplined by the hut-builder. The individual is far more complex than its place in a larger unity would indicate. For Tarde, as Latour puts it, "the big is never more than the simplification of one element of the small" (123). Each branch, Tarde would claim, using the Leibnizian vocabulary of his Monadology and Sociology (1893), contains the entire tree monadically, the tree being entailed in every branch. We might also recall Viollet-le-Duc's detail drawing, in which individual elements literally commit only certain facets to the whole, or the barricades comprised of elements with allegiances elsewhere.

Tarde recognises that the emergence of theories of the crowd is not just the prompt for a new social theory. It requires a wider-ranging theory of assemblage. Tarde has little, if anything, to say about architecture under that name. But the theory of assemblage he develops has direct relevance to some of the most fundamental architectural questions: how parts are put together in service of some greater unity. His thinking may seem excessively abstract, but in fact it is highly concrete. What Tarde proposed was that, in any circumstance where we confront an assemblage, we should not immediately interpose a greater unity to which it belongs, but should examine the processes and networks of interaction at work. Put simply, our concern should be formation rather than form.

\section{Conglomerates as an architectural problematic}

When Sloterdijk discerns an "architectural problematic" in the new social assemblages of the French Revolution, it is important to recognise that this is not merely a matter of society's implications for architecture, nor conversely, architecture's implications for society. Sloterdijk says that the very subjectivity of crowds depends on the production of space: 
the forming of a multitudinous, metropolitan crowd into a present mass was an architectural, organisational, and ritual task ... 'The masses', 'the nation', or 'the people' can only exist as a collective subject when the physical assemblage of the magnitudes is the object of an elaborate production. (2007: 75)

Architecture, society, culture, technology - these cannot be seen as autonomous fields, even overlapping ones.

It is admittedly unorthodox to argue that the form of crowds and building tectonics can be connected in anything but a symbolic register. To take this further step, however, it is only necessary to recognise that both domains are structured by a theory of assemblage, even though this theory often remains implicit. Having recognised this, the relationship that Rykwert indicates between Rousseau's social contract and Laugier's primitive hut can be seen to be more than analogical.

I have had two aims in this paper. The first of these has been to indicate the value of examining implicit theories of assemblage for historical understanding. The organisation of collectives and understandings of architectural organisation describe an interwoven trajectory. The disengaged assemblage that structures Rousseau's and Laugier's respective arguments is drastically shifted by theories of the crowd. Haussmann, who implicitly shares Le Bon's theory of assemblage, sets in place an architecture of resistance to the crowd, while Viollet-le-Duc's organicism hints at a reformulation of architecture more sympathetic to the crowd.

My second aim is projective and open-ended: to seek a trajectory for this analysis into the present. ${ }^{13}$ Architectural assemblage and social assemblage should not be seen as problems from entirely separate domains. It is not a matter of discerning how one domain informs the other, nor a matter of delimiting an area of overlap between them. In place of many separate and communicating discourses of assemblage, Tarde proposes a unified discourse of assemblages governed by relations of exteriority. ${ }^{14}$ His treatment of the structure of crowds and structure of architecture as cases of a more general theory of accumulation, conglomeration, and multiplicity is a radical restructuring that should drive us to renewed questioning of the relationship between architecture and society, and would result in a more fluid, precise, and intricate view of both.

\section{References}

Benjamin, W. (1999). The Arcades Project (H. Eiland and K. McLaughlin, Trans.). Cambridge: Harvard University Press.

Bergdoll, B. (2001). European Architecture 1750-1890. Oxford: Oxford University Press.

Canetti, E. (1966). Crowds and Power. New York: Viking Press.

De Landa, M. (2006). A New Philosophy of Society. Assemblage Theory and Social Complexity. London: Continuum.

Deleuze, G. (2004). Difference and Repetition (P. Patton, Trans.). London: Continuum.

Douglas, C. (2007). Barricades and Boulevards: Material transformations of Paris, 17951871. Interstices, v8. pp 31-42.

Frampton, K. (1995). Studies in Tectonic Culture: The Poetics of Construction in Nineteenth and Twentieth Century Architecture. Cambridge: MIT Press.

van Ginneken, J. (1992). Crowds, Psychology and Politics 1871-1899. Cambridge: Cambridge University Press.
13. There is not room here to follow the twentieth-century career of theories of the crowd. Le Bon sets the tone for much of this career: Freud follows him for the most part. Canetti's Crowds and Power (1960), a freeform treatise on human social behaviour, was influential, but it was not until empirical studies of the 'emergent' behaviour of crowds, flocks, and herds appeared in the later part of the century that a distinctly separate theory of assemblage can be discerned. See, for example, Kelly (1995), a popular account of this new research. A more intensive account is found in De Landa (2006).

14. The term "relations of exteriority" is Deleuze's. See De Landa (2006). 
Hobbes, T. (1998). Leviathan. Oxford: Oxford University Press.

Kelly, K. (1995). Out of Control: The New Biology of Machines, Social Systems, and the Economic World. London: Fourth Estate.

Latour, B. (2001). Gabriel Tarde and the End of the Social. In P. Joyce (Ed.), The Social in Question: New Bearings in History and the Social Sciences, (pp. 117-132). London: Routledge.

Latour, B. (2005). Reassembling the Social: An Introduction to Actor-Network-Theory. Oxford: Oxford University Press.

Laugier, M.-A. (1756). An Essay on the Study and Practice of Architecture. London: Stanley Crowder and Henry Woodgate.

Le Bon, G. (2001). The Crowd. A Study of the Popular Mind. Kitchener: Batoche Books.

Lovejoy, A.O. (1923). The Supposed Primitivism of Rousseau's 'Discourse on Inequality'. Modern Philology, v21, n2 (Nov), 165-86.

McEwen, I.K. (2007). Lines of Fire. Architectural Theory Review, v12, n1, 60-77.

Moscovici, S. (1985). The Age of the Crowd: A Historical Treatise on Mass Psychology. Cambridge: Cambridge University Press.

Philippe, S. (1989). Les Barricades. Architectural Review, 186 (1110, August), 84-86.

Rousseau, J.-J. (1968). The Social Contract (M. Cranston, Trans.). London: Penguin.

Rykwert, J. (1981). On Adam's House in Paradise: The Idea of the Primitive Hut in Architectural History. 2nd ed. Cambridge: MIT Press.

Sloterdijk, P. (2007). Foam City. (J. di Filippo, Trans.). Log, v9. pp 63-76.

Sloterdijk, P. (2005). Sphéres III: Bulles. (O. Mannoni, Trans.). Paris: Maren Sell Éditeurs.

Tarde, G. (2002a). Les Lois Sociales: Esquisse d'une Sociologie. Retrieved 28 March, 2009 from http://classiques.uqac.ca/classiques/tarde_gabriel/les_lois_sociales/les_lois_sociales.pdf

Tarde, G. (2002b). Monadologie et Sociologie. Retrieved 28 March, 2009 from http://classiques.uqac.ca/classiques/tarde_gabriel/monadologie/Monadologie_et_socio.pdf

Viollet-le-Duc, E.-E. (1987). Lectures on Architecture. 2 vols. New York: Dover Publications.

Wigley, M. (1993). The Architecture of Deconstruction: Derrida's Haunt. Cambridge: MIT Press. 